\title{
Narrative Transformations in Cultural History
}

\section{Korhonen, Anu}

Transcript verlag

2015

Korhonen , A 2015 , Narrative Transformations in Cultural History . in S Georgi , J llgner , I Lammel , C Sarti \& C Waldschmidt (eds), Geschichtstransformationen : Medien, Verfahren und Funktionalisierungen historischer Rezeption. Mainzer Historische Kulturwissenschaften , Transcript verlag , Bielefeld, pp. 31-51.

http://hdl.handle.net/10138/154760

acceptedVersion

Downloaded from Helda, University of Helsinki institutional repository.

This is an electronic reprint of the original article.

This reprint may differ from the original in pagination and typographic detail.

Please cite the original version. 


\section{Narrative Transformations \\ in Cultural History}

ANU KORHONEN

Dieser Artikel perspektiviert Ansätze von Geschichtswissenschaftlern und -theoretikem, die Historiografie zu erneuem, und diskutiert, inwieweit diese Vorschläge unsere Art und Weise, Kulturgeschichte zu schreiben, ändern könnten. Kulturhistorische Erzählungen basieren, so die Annahme, anstatt auf einem kausalen oder chronologischen Emplotment wie viele Theoretiker narrativer Geschichte behaupten, auf einer Logik des Kontextes. Die aktuellen Diskurse haben das Bewusstsein für den konstruktiven Charakter jeglicher Geschichtsschreibung geschärft. Ausgehend von Elizabeth Ermarths theoretischen Maximen, Michel de Certeaus, Greg Denings und anderen Arbeiten plädiert dieser Artikel für die Nutzung narrativer Verfahrensweisen und Strategien, die beeinflusst sind von unserem gegenwärtigen Verständnis der Beziehung zwischen Vergangenheit und Gegenwart, und dafür, experimentelle Repräsentationsmodi von Vergangenheit zu erproben. 
You don't need to know everything. There is no everything. The stories themselves make the

meaning.

The continuous narrative of existence is a lie. There is no continuous narrative, there are lit-up moments, and the rest is dark.

Jeanette Winterson Lighthousekeeping (2005)

How are we to write history? What are the conventions that signal a text's belonging within the sphere of historical scholarship, and what should we think about these conventions? In recent years, discussions about the nature of historical writing have not only charted the techniques and logics of creating historical narratives but have also called for active subversion, inventive and creative approaches that tell about the past in new ways. But what might this suhversinn lnok like in nractice? In this essav. I will consider suggestions (history not as the archival reconstruction of what happened but as the continuous contest over how the past is approached or invoked)". 2

While many historians, of course, have continued writing and teaching as if nothing much had happened, others have taken the challenges very seriously. Cultural history, for example, would not exist as a disciplinary field if the above-mentioned debates had not called it into being. And yet the contests over the meanings of history and its operations still continue today. Tensions between polarized stances have not abated. Perhaps surprisingly, at least from a cultural historian's point of view, some have now thankfully pronounced the death of the postmodern, expecting a return to 'business as usual'. Cultural historians have no such luxury: there is no way back to the realist nationalist epistemologies that privilege the white, male and Western vantage point, and there is no escape from the theoretical advances that have transformed history, too, from "an experimental science in search of law" into "an interpretative one in search of meaning", as Clifford Geertz suggested for anthropology in the early $1970 \mathrm{~s}^{3}$

The challenge from nostmodernity has alsn enoendered a srhnol of

2 ELEY, 1999, p. 214

3 GeERTZ, 1973, p. 5. The various challenges history has faced are neatly summarized in RADDEKER, 2007, p. 33 
impression that the past is writing itself, without the interpretative actions of a historian. ${ }^{4}$

'Practising historians', a term sometimes used by the narrative theorists to refer to those of us who still try to engage with the past, tend to see things slightly differently. The concept of narrative that these historians employ, more or less consciously, is significantly wider than White's formulation that comes to a large extent from classical rhetoric and does not make extensive reference to narratology nor to other more recent debates on narrativity. ${ }^{5}$ The heightened interest in narrative within historiography may actually be more closely linked with French cultural theory, especially poststructuralist and postmodern critiques of knowledge, than the Whitean tradition. ${ }^{6}$ Cultural or intellectual historians, for example, rarely present their own stories in the way depicted by White and his followers, because they rarely understand the craft of the historian as simple faithful representation of past events. ${ }^{7}$ White's statements about narrative were not only closely linked with the topic he was mostly studying, nineteenth-century French historiography, but also with the wider problem of whether history could be called a science, a question more acute in the 1970s and early 1980s than for the cultural and intellectual historians of today. After the cultural turn, attempting to evaluate historiography through the traditional cognitive models of the natural sciences would seem a futile exercise. Rather, the narrativity of history is now taken to refer to a mode of experiencing temporality, following Paul Ricœur, or in wider terms to the value of narrative as a mode of understanding and the production of meaning in general. ${ }^{8}$ The value of White's contribution for historians, then, has mostly lain in an increased awareness of the constructed nature of all historiography.

4 WHTtE, 1987, p. 2f., 24; WHTtE, 1999, p. 8f.; see also MUNSLOW, 2007, p. 3f.; MUNSLOW, 2003, p. 13, 20-23

5 Matti Hyvärinen's work on the conceptual histories of narrative helpfully traces the genealogies of the different usages of the term and can also help historians redefine their understanding of narratives, see for example HYVÄRINEN, 2006 and 2012.

6 GunN, 2006, p. 27

7 Alun Munslow calls historians who represent this position culturalists or deconstructionists, as opposed to the more traditional constructionists and reconstructionists. His terms differ somewhat from the wider epistemological debates on constructionism, raging over all human sciences. See MuNsLOw, 2003, p. 142-144; ID., 2007 , p. $10-15$

8 PARTNER, 1986, p. $91-94$; KANE, 2000, p. 315 f.; SEWELL, 2005, p. 218f.; GuNN, 2006, p. 34.
One of the pet hates of narrative theory of history has been the naivve belief adopted by most historians, as the narrative theorists would have it, that their stories immediately represent the past. Narrative theory of history has not, overall, been as interested in the narrative practices of historiography - what kinds of stories do we actually now write - as in debating whether the past takes the form of a grand narrative - "does the story of the past actually exist to be 'found"', as Alun Munslow puts it. ${ }^{9}$ But who is the opponent in this debate? Do historians really assume that the past itself arranges itself into a narrative, or do they see themselves as the organizers of the narratives they posit? I would argue that very few historians are as naïve as the theorists like to think, but the debate itself has been useful. Positing that historical stories are just stories, as fabricated and crafted as any works of fiction, serves as a healthy reminder that historians' work is much more complicated than it seems.

The debates about the fictiveness of historical writing have been important for many reasons, but among them is surely an intense interest in how we write what we write, and what we think we are doing when we attempt to represent the past. It is not particularly newsworthy to announce that historians are creative writers and that they should be able to write well, but these days the demands for writing creatively and unconventionally go much deeper. After everything that the linguistic turn forced us to think about, no one can be ignorant about form carrying content, too, and thus our creative efforts must also address the problem of what our writing does with the thing represented, the past itself.

It is now widely acknowledged that historians cannot hide behind the belief that when writing about the past they are referring to a reality 'out there', unorganized by discourse - this gesture would let what is thoroughly representational masquerade as purely referential. ${ }^{10}$ And yet, even when we abandon the assumption that the past is out there to be found, we continue to refer to traces surviving from the past, and anchor our interpretation on these traces. Referential practices still shape historical discourse and representations, and must continue to do so for as long as we believe in history as a mode of knowledge at all. ${ }^{11}$ It is important to maintain, however, that in a sense our histories

9 Keith Jenkins, for one, consistently argues that this is still the case, see JENKINS, 2003; and MUNSLOw, 2007, p. 3; MUNSLOw, 2003, p. $77 \mathrm{f}$

10 My formulation comes from HaltTUNEN, 1999, p. $166 \mathrm{f}$.

11 Pihlainen, 2002, p. 50-54. In his article, Pihlainen also usefully discusses the historian's role as narrator in historiography. 
are not as much about the past as such; rather, they are attempts to make sense of its textual and material traces. These remnants are only infused with historical meaning through the historical operation, including its storifying function. ${ }^{12}$ The fundamental challenge for historical writing, then, is how we understand and construct the relationship between historical traces and their vanished temporal contexts.

The form that historical narratives now often take is a negotiation between two imagined temporal layers, and this is perhaps true of cultural history narratives in particular: the historian's present where his or her story is told, and the reported past, represented by its traces. On the level of the historical narrative, these traces are not just something we talk about - we bring them to bear directly on the narrative itself, letting them intervene in our story, as if they were a partner in discussion. In terms of what we want to talk about, the traces have no interests or intentions - they do not particularly want to tell us anything, and they have no control over what we imagine or describe. However, at least partly, we act as if they had. We imagine them to at least have an interest in being represented truthfully, which is why we let their voices be heard in the midst of our own narratives. We write footnotes and references, collect lists of texts cited and use heaps of quotations. It is crucial to the textual arrangement of historical stories that they are anchored in other texts. No amount of linguistic, cultural, discursive or postmodern turning has changed this, although we can, of course, think of new and exciting ways to arrange and shape that anchoring.

\section{Context and articulation}

As I claimed earlier, the organizing principle of most cultural, social and intellectual history narratives now tends to look rather different from the chronologically emplotted narratives of Whitean theorists. But if stories in cultural history are not structured by a logic of causality and chronology, how are they organized? In post-linguistic turn histories, the logic that characterizes both thinking and writing more accurately is contextual framing. Indeed, in much theoretical writing by practising historians, contextualization in its

12 FulbrooK, 2002, p. 107. various guises has been a constant call for action in the last $20-30$ years. But what do we mean by context, and how are contexts constructed?

Abandoning the realist epistemologies that conflate the past and its historiographical representation have also called into question many of the critical procedures traditionally counted amongst historical source criticism. This has highlighted the status of contextualization as history's method, forcing us to look for characterizations that would sustain its place in the newer cultural epistemologies. Here, cultural history can learn from cultural studies, where a lot of energy has been spent on discussing the notion of articulation, the practice of making connections that facilitate networks and flows of meaning. Lawrence Grossberg, for example, cites the notion of articulation as the only possible method in his field: "cultural studies [...] does not have a 'method', unless one thinks of articulation - the reconstruction of relations and contexts - as a method". ${ }^{13}$ This is one of the key strengths of cultural analysis: by making connections, by bringing to light the processes of articulation, we can reach interpretations that have the potential to be both innovative and enlightening. But here, I think, also lies one of the potential weaknesses not only of cultural studies but also of cultural history: how to theorize the articulations between cultural phenomena, texts and discourses, and processes of signification? If there is no grand narrative of historical development, then there is no unified past either, and not all our texts, materials and contexts are perhaps connected quite as strongly as we may like to think. What, then, constitutes the basis for articulations and connections, or contexts, within historical interpretation? A wealth of examples and anecdotes does not necessarily amount to a strong argument, ${ }^{14}$ and here, I would suggest, we need to think about our theories of meaning more closely.

The problem, to my mind, is that in more traditional historical thinking the idea of context has been envisioned referentially. For such historians, a context would be constituted by ideological and material divisions in an assumed reality that their sources represent. The studied detail or fact becomes understandable by reflecting it against the reality of the past, by surrounding it by interpretative bits and pieces, collecting evidence and proving its connectedness to the topic in terms of 'critical procedures'. All this takes place in neutral time, in a temporal context of periods and chronologies that is assumed

13 GROSSBERG, 2010, p. 52. The concept of articulation typical of cultural studies derives from Emesto Laclau and Stuart Hall, see SLACK, 1996, esp. p. 115-117.

14 SEWELL, 2005, p. 11f. 
to govern not just the discourse of historiography but the past itself. The contextual matter that the evidence constitutes then turns, as needed, both into the specific focus of the work and into a perspectival light-beam that reveals and explains it.

A cultural historian, I would argue, should envision her context in a different way. Emerging from a thorough immersion in the linguistic and cultural turns, she would be more interested in following the play of meaning that her texts take part in and see them as constituents of contestations within to use Foucauldian concepts - specific discourses, epistemes or genealogies. She would find it central to ask what ways of reading and interpretation the studied cultural details or texts allow and what they resist. She would read for interpretative possibilities, alternative ways of knowing, internal inconsistencies, aporias, fractures and ambiguities. ${ }^{15}$ And what she would come up with would again be possible 'readings' of a text and the processes of signification it may have helped to construct. In this way, a context, or a range of articulations, would offer itself as an aid to different interpretations, but it would not penetrate the focus of the study itself, nor masquerade as a raw fact of the past. In sum, if meanings are born differentially in signifying practice, following these operations of difference through our sources should enable us to reconstruct complex fields and frames of meaning - this is the practice we could call contextualization.

Now what would this mean in terms of how we construct our narratives? It would certainly entail putting into words a prism of fractured and sometimes contradictory bits of story, refusing closure and doing away with the smooth surfaces of emplotment. Could this be seen as an unconventional narrative within current historical writing? Perhaps. But it would also be standard practice for cultural historians, whose books and articles are often arranged into chapters that offer a perspectival prism from which their topic could be made sense of, and whose endings are left open not only in terms of sequences of chronological change but also in terms of which of the different interpretations will finally win the day. Cultural historians are trained to feel comfortable with ambiguity and contradiction, and their stories rarely have the beginning, the middle and the end of the causal chronology criticized by narrative theorists. It is perhaps necessary to note that although cultural historical narratives do not proceed in chronological sequence, no historian could abandon chronology as a basis of their temporal ontology. Time does,

15 FULBROOK, 2002, p. 104. however, appear as "fateful, contingent, complex, eventful, and heterogeneous", as William Sewell has suggested. ${ }^{16}$

In terms of the kind of history that narrative theory of history describes, then, the standard cultural history narrative must be seen as unconventional, because, while the events of the past that it describes may well have happened in a chronological sequence, they do not follow that sequence in the interpreted form that is the historian's writing, and while its themes are emplotted contextually, they do not follow one from another causally. If cultural historical narratives are made up of events following one another, we have to think about events as knots of discourses coming together and generating meaning, or as sets of actions where discursive codes are instantiated. Our events are not, for example, traditional political events whose place and meaning is always-already defined and known. In cultural history, contexts open from the differential operations of meaning: if meaning is always generated by differentiation, it is by charting the discourses in which that play of signification takes place and by pinpointing where meaning strains against its boundaries that contextual confines, too, can be envisaged. Mapping the differential operations of meaning, the core problems that we focus on will open towards their manifold cultural manifestations and articulations, and, if culture is the web in which all meanings are suspended, then outlining these operations also means spinning the web of culture.

\section{Invention and imagination}

Many historians talk about how the traces from the past, too, often present themselves to us as ready-made narratives, as stories people told about real or imagined events, while, at the same time, fashioning discrete symbols into intelligible sequences in order to construct an understanding of the world they were living in. The people of the past, as much as we now, made use of preconceived tropes and narrative structures that could offer them a basis for making meaning, a basis that would tie together different aspects and interpretations of what was happening in an always-already apprehended form. Robert Darnton and Natalie Zemon Davis both already contemplated this when writing their classic studies of new cultural history: Darnton on a Parisian cat

16 SEWELL, 2005, p. 11. 
massacre, Davis on the return of Martin Guerre. Both used sources that had already been fashioned into stories by their informants and were in that sense already interpreted versions of events. As such the stories entailed a communicative framework where the anticipated listeners, tellers and characters of the narrative had their own cultural settings; the raw material of experience had already been turned into a meaningful sequence and shape Darnton commented on the reluctance of traditional historiography to confront the narrative situation - where could we find 'the truth' if everything was already a story, a version, an interpretation? According to Darnton, if we are looking for understanding from the outset, we should be happy if the past reaches us in the narrative form that expressly communicates interpretations and understandings. It is exactly by treating all narratives from the past as 'fiction', as meaning-making fabrication and interpretive craftsmanship, that we can develop our own methods of interpreting and understanding. ${ }^{17}$

This idea has been a fruitful starting point for many historians who frame their interest not as "the traditional question: what was the true story of what actually happened", but instead want to "write a history of the accounts, narratives, stories built around" the topic they are researching and ask "what does this story mean, and why did it take a particular form at a particular time". ${ }^{18}$ These formulations come from John Brewer's book Sentimental Murder, an analysis not just of a murder case in the eighteenth century but of the accumulation of stories about that case, a study that Brewer expressly frames as a partial answer to the demands that narrative theory has posed to historical writing:

If we (including historians) are all implicated in the stories we tell, then I, too, have an obligation to explain my own narrative. What am I up to in writing about more than two centuries of stories about a crime of passion which, though terrible for those immediately involved [...] hardly seems the stuff of 'history'? The answer to this lies, I believe, in my response to the sometimes rather bruta debates that have taken place over the last twenty years or so between two very different notions of history: one that emphasizes that history is the recovery of what actually happened in the past; the other that history is made in the present, the plotted and imaginative construct of a modern historical narrator. ${ }^{19}$

17 DARNTON, 1984, p. 82; see also DAVIS, 1983

18 BREWER, 2005, p. 4f.

19 IBID., p. 7
Even though the negotiations about the historian's role in manipulating the stories surviving from the past and in constructing the past culture only through their own narrativizing efforts have taken many forms, Brewer's answer is typically self-aware: for many, these debates have meant adopting a more clearly delineated stance towards theories of meaning and the concept of culture, as well as a more consciously problematized relationship with the historian's object itself.

Some experiments represent this questioning in rather drastic form, testing the very truth value of historiographical statements. Simon Schama was among the first to do so: in 1991, he published Dead Certainties (Unwarranted Speculations), seeking to point out that almost nothing about historical analysis and writing is ever dead certain, and that many of historians' big conclusions on closer inspection turn out to be unwarranted speculations. In his own narrative, Schama combined standard empirical analysis with pure fiction, but presented it all as if it were gold-standard scholarship. Without going through his evidence, we would never have been able to tell which parts of the story were true and what was only a product of his imagination. In his conclusion, Schama lets us in on the game: the aim of this exercise was to follow the broken and interrupted narratives that the past presents us with, and "play with the teasing gap separating a live event and its subsequent narration":

These are stories then, of broken bodies, uncertain ends, indeterminate consequences. And in keeping with the self-disrupting nature of the narratives, I have deliberately dislocated the conventions by which histories establish coherence and persuasiveness. Avoiding the framing of time-sequences supplied by historical chronologies, the stories begin with abrupt interventions - like windows suddenly opened - and end with many things unconcluded. (The 'Conclusion' that every doctoral adviser urges on his students as a professional obligation has always seemed to my notoriously inconclusive temperament to be so much wishful thinking. $)^{20}$

Events in history rarely end, especially the kinds of discursive events that cultural, intellectual and social histories are mostly concerned with; historical writing, however, is usually limited by numbers of characters and pages. The stories of the people we write about seldom end with our endings.

20 SCHAMA, 1991, p. 321 f. 
This impression of events and stories of the past rarely conforming to the structures of the historian's argumentation also troubled David Cressy, a social historian working on early modern Britain, who immersed himself in the "sea of stories" that formed the evidence for his book Birth, Marriage and Death (1997). He was confronted with so many interesting but marginal cases, narratives which did not fit the frame of his overall argument, that he felt he also had to do something with the strangely inspiring oddities. He contemplated three different possibilities that may help us differentiate between competing research strategies more generally: first, he could summarize the incident or the narrative, then relate it to "mainstream history" and to a standard historical interpretation, where it would shed "an unusual sidelight" on the standard frame. Second, he could "impose a specialized interpretative framework" of, say, local history, legal history, history of childhood or history of sexuality, and explicate his case through the conceptual workings of that frame, however violent that might seem in terms of what the stories themselves seem to say. Third, he could "lay out the information, in as complete a form as possible, and follow where it leads". Vague as the proposal seems, it is the third option that allows most room for unconventional ways of presenting the fruits of the historian's findings, Cressy suggests:

We may $[\ldots]$ find ourselves dealing with a fractal narrative, with endlessly multiplying connections and connotations, thickening layers of significance, and no clear sense of closure. Madness may lie in that direction, but so too might a richer sense of the complex culture of early modern England. ${ }^{21}$

What Cressy came up with can be witnessed in Travesties and Transgressions (2000). Despite his inspiring speculations, the book appears to a specialist reader more as a random collection of intriguing anecdotes than an especially good example of a new paradigm of history writing. One of his suggestions, however, is especially interesting for our purposes: discussing the case of one Agnes Bowker and her cat in 1569, Cressy thinks about the ways in which stories from the past intertwine with stories of today. As the most fruitful strategy for historical interpretation he posits "a double set of negotiations, a nested epistemology, involving present and past", where both the level of the past and the level of the present involve processes of making and deciphering meanings. For the analyst in the present, however, the past will remain "alien

21 CRESSY, 2000, p. 7-9. and elusive"; it will take "us into the realms of uncertainty, indeterminacy, and ambiguity, the shifting grounds of bewilderment and wonder". ${ }^{22}$ It is this engagement with the other that also has the potential to change the self, that can be recorded in the histories we write, not the elusive past itself.

A better known example of this technique is Michel de Certeau's discussion of demonic possession in the seventeenth century, The Possession at Loudun, published in 1970 - earlier than my other examples and indeed before the current debates about narrative were even started. Certeau's narrative choices may at first seem somewhat perplexing, but on closer inspection they start to take the shape of an imaginative reformulation of the relationship between past traces and their readings in the present. Certeau, too, gives us plenty of quotations from his sources, but he refuses to analyze his excerpts; on the contrary, he uses them to astound the reader by their strangeness and incomprehensibility. He will not tell us a story but instead concentrates on whichever character or event seems to take his fancy - thus showing us that there indeed is no consistent, unbroken story in the past to be found. He does not look for a totality of meaning, but presents us with aporetic tensions and impasses in past discourses that will not take clear shape even under the organizing gaze of the historian. The inconsistencies and contradictions of the past are no basis for a unified interpretation, then, but for a multiplying and perspectival series of questions that one can pose when confronting its traces. The whole dramatis personae and the series of events at Loudun seem to serve, in the end, as an attempt to delineate the boundaries and the epistemological structures of historical scholarship, rather than of what was going on with the possession cases themselves. By its very representation, the Loudun case refutes our belief that the past can be intelligible in and of itself, and instead suggests that it is the historical operation that organizes and constructs past events into intelligible sequences and narratives. ${ }^{23}$

What all these exceptional epistemological and narrative choices have in common is that they do not facilitate a satisfying reading experience for someone who is used to traditional historical narratives. We seem to be deceived, even though these writers in actual fact expressly refuse to deceive us in the ways that we are accustomed to. Their texts do not follow the analytical and argumentative structures that we are all taught - and by which we are also judged when our theses are examined or our articles peer-reviewed

22 IBID., p. 26.

23 Certeau, 2000. 
for academic journal publication. Doing what they do would quite probably not give us a doctoral degree, and it might well keep us from getting our efforts published - most peer reviewers are notoriously unenthusiastic about experimental narrative choices. It may be hard to find evidence for this in published work, but Thomas Cohen, a historian who habitually trespasses on the narrative grounds of literary prose and pushes the boundaries of conventional historical expression, comments on the problems of finding an outlet for more unconventional work in his Love and Death in Renaissance Italy (2004), a book we will soon return to:

I tried my draft on a solid joumal. Two assessors opined, firmly and unhappily, that, clearly, this was a beginner's lame effort. A sobering day for me! Clearly, I fumed, follies such as mine should be a sign of longer aging. I gnashed my teeth, lamented with my colleagues, and gamely tried another learned publication. The assessor's word came back: good stuff, but I wager the board will never have it. Prophetic! And it is too long; why not, the reader asked, make a book of it? ${ }^{24}$

Cohen's always inspiring work has been published both in journals and in books, of course, and indeed there are a few journals that expressly pursue experimental work. ${ }^{25}$ Still, chances are that if an author's aim is to try out something different from straight academic history, it may be hard to find a place for publication.

Where peer reviewers guard professional standards, the texts I have cited expressly flaunt them: not only do they subvert narrative conventions, they also may not focus or present traditional research problems, or guide their reader towards totalizing interpretations in the way that feels comfortable to us. In terms of both historical theory and historical narration, they continuously draw the carpet from under our feet. The past no longer seems accessible and distinct, a problem to be solved or an object to be described - it cannot be reached with the sleight of hand that we are accustomed to performing

24 COHEN, 2004, p. 69.

25 One such example is Rethinking History, a journal that identifies itself as an arena that "allows historians in a broad range of specialities to experiment with new ways of presenting and interpreting history. Rethinking History challenges the accepted ways of doing history and rethinks the traditional paradigms.", https:// www.facebook.com/RethinkingHistory, 13.09.2014. See also the special issue on Unconventional Histories in History and Theory 41, 4 (2002). ourselves. Instead, these writers struggle to reveal the fictive, crafted nature of historical storytelling - but not as abstract theoretical statements, in the manner of narrative theorists of history, but through their own narrative choices and the epistemological structure of their work. This is why their stories seem fragmentary, dissolving into the unbridgeable gap between the past and the present.

\section{Performance}

The historians I have drawn from hardly intended their experiments as examples of a whole new paradigm that their colleagues were supposed to follow; rather, they meant to reflect on the small print in the contract of 'how we do things', partly as a learned game and partly as questions posed to the community of historians. But if our conception of the ontological status of the past within historiography has changed, our narratives, too, seem open to reworking. One aspect where a change has definitely occurred across a broad spectrum is the amount of self-reflexivity: the authorial role of the historian no longer needs to be hidden, whether it emerges as an explicit narrator or works from behind the scenes like a stage director.

It has indeed been a theatrical metaphor that has guided some of the bravest attempts at a new kind of writing. Many now recognize that history-writing is a kind of performance, both in the sense inspired by Judith Butler - we start to recognize it as a discrete discursive activity when its gestures and operations are repeatedly performed - but also in the sense described by Greg Dening, a historian and anthropologist whose books and articles explore the various meanings of performance in a strikingly imaginative way while also questioning the most fundamental principles of historical presentation. Dening's book Mr Bligh's Bad Language: Passion, Power and Theatre on the Bounty (1992) is deservedly often cited as a prime example of historical experimentation.

In Dening's hands, what in many ways represents all the hallmarks of meticulous scholarship - an array of historical sources, a base in a traditionally emplotted event of the voyage of the Bounty and a solid focus on what happened and why - takes the form of a play. Starting with a prologue followed by acts and scenes, its narrative resembles the fractured chronology, disruptive reflexivity and interwoven webs of relations of modern prose. Dening himself 
enters his story from the beginning, in the disguise of the deliverer of the prologue, and proclaims his intentions as a historian intrepidly if metaphorically:

$[T]$ he deliverer of the prologue enters by a 'stage door' that is not part of the scenery but marks a special entry place of someone who for the moment is neither actor nor audience, but in between, distant by being a didact, dangerous by being an ironist, disturbing by being a relativist. On him or her there traditionally focused a deep antitheatrical prejudice. The imagination he or she sparked was dialogic and by that the audience was enticed into the conspiracy of its own engagement in making realism. For those convinced by religion or politics or philosophy that realism was not their own making, this representative of representing was a very dangerous clown. ${ }^{26}$

The irony, didacticism and relativism here are not just qualities of the deliverer of the prologue but of the historian, who also has a special entry place of someone neither actor (in the past) nor audience (of his histories) and who can, at times, become a dangerous clown, with a dialogic imagination filled with cultural theory. Dening's is indeed a virtuoso performance, but other historians, too, have made use of theatrical effects. Natalie Zemon Davis, always a courageous explorer of historical performances, imagined herself in conversation with her protagonists in the prologue of Women on the Margins (1997) and Thomas Cohen acted as a stage director when presenting the sixteenth-century case of The Last Will of Vittoria Giustini, a chapter included in Love and Death in Renaissance Italy. Cohen was first drawn in by a female member of the Giustini family, Silvia, but, accommodating for all the different voices in his source material, he needed even more creative 'carpentry' than usual to get the story right:

To make sense of her, and the whole story, I played my usual tricks, building a list of characters, with their assembled traits, and filling out a time-line of speeches, entreaties, curses, and blows. But, this time, so many were the witnesses that description thickened to the point that, for much that happened, my time-line acquired long strings of dialogue. It is a soap opera, I thought, and presented it that way, speaking in some two dozen voices, for a seminar. I had planned to slide my whole running commentary into the stage directions. But

26 DENING, 1992, p. 3 since I knew too much, observations spilled over into a prologue, an epilogue, and two entr'actes. ${ }^{27}$

Davis's and Cohen's theatrical effects are not just echoes of Dening's investigative performativity but playfully serious attempts to rethink the historical operation and particularly its storytelling function. History is about relation-ships set in a complicated temporal frame, where the author translates other voices through his own narrative arrangement but also with anticipated readers in mind.

Dening has indeed stressed the dialogic nature of academic writing; for him, it needs to be performed with an audience in mind, as a conversation, and it needs to be performed not according to the formalities of professional rules but by consciously twisting the rules to test their function and purpose. In Beach Crossings (2004), a book that again represents a voyage - this time revisiting the beaches of Oceania and the notion of the beach as limes, as well as the intellectual autobiography of this major scholar - Dening summarizes his legacy to his students and advices us all on how to write history. "Be mysterious", he says, "be experiential", "be entertaining", "be compassionate", "be performative" and "be reforming". The reason for writing is a will to change the world, even if writing "is like dropping a rose petal into the Grand Canyon and waiting for a bang". For Dening, the justification for history writing can be found in the present. ${ }^{28}$ If these formulations necessarily evoke the idea of a creative writer, Dening also turns the tables and evokes the partner in crime, the creative reader, for whom we write:

We have to liberate the creative reader, I say. Stir the exegete, make the critic, let them hear the global discourse that is the white noise behind all our disciplines. What tricks do we have for that? Aphorisms? Riddles? Perspectives of Incongruity? Metaphors? All of those. Our readers need to be rid of their fear of flying. They will not lose theirs if they catch ours. ${ }^{29}$

It is brave performances that Dening is calling for, then, but performances that also aim to make a difference both in our acts of writing and in the world at large.

27 DAVIS, 1997, p. 9-13; COHEN, 2004, p. 69-73.

28 DENING, 2004, p. 265 and 268.

29 ID., 1996, p. 116 
Even if Dening's metaphors, riddles and incongruities are a good start, it has been patently difficult to suggest new shapes and models for a radically new kind of history writing, not least because, as Keith Jenkins has pointed out, looking for such models must itself be interpreted as a continuation of the modernist project that postmodern history has been looking to condemn. ${ }^{30}$ Consciously flouting these threats, the literary theorist Elizabeth Ermarth has presented us with the most detailed and imaginative programme so far for a new kind of writing, in her many articles and in her book History in the Discursive Condition (2011). Her characterizations bring to mind many of the examples cited above, but they should inspire us to think even further.

Guided by her favourite novelist Vladimir Nabokov, Ermarth calls her thought-provoking model "anthematic narrative", evoking the Greek word for an especially complicated, many-layered and intertwining floral design. Many of the characteristics of Ermarth's anthemion we have already encountered, but rather than a theatrical metaphor, she gives her textual organization a visual shape. By collecting together so many of the diverse elements that a new way of history writing might want to employ, the anthemion will serve here as a summing up of how we might want to proceed. There are many facets to Ermarth's argumentation that we may want to discuss, but let us concentrate here on just a few.

When she takes up the linguistic forms we use to hatch our plots and research themes, Ermarth wants to replace our typical research agenda based on standard emplotment and characters with a new thematic alphabet where symbols and details would be considered as systemic elements, as constituents of the code of our discursive understanding. In Ermarth's opinion, our representation or image of the past should be replaced with patterns and designs through which we aim to understand it. She advises us to look for new narrative solutions through the rhythms, rhymes and melodious qualities of language. She asks us to bend our thematic sequences rather than organizing them into sequential causal plots. Difference and differentiation are more important than similarity or sameness, if we want to face the alterity of meanings that the past necessarily represents. Like most of the historians I have mentioned, she desires breakages, disturbances and noise in the narrative to interrupt our customary interpretative flow - narrative here would advance as a kind of straying, stepping off the path and returning, taking detours into new views and propositions. Ermarth's historian would make his or her reader, too,

30 JENKINS, 2003, p. 6. conscious of the constructed nature or scholarly narrative and refuse to present it as natural or foundational - she would not just attempt to represent the past but would stress the inventive, creative quality of her craft.

Ermarth's most fundamental proposition is that the past should not be presented spuriously as something that can be simply found or as a temporal underpinning that supports our present but as a product of an active interpretative gesture. The past exists to us as our speech about the past, as what and how we say about it; it cannot present itself to us in and of itself, despite the traces that it has left for us to decipher. The past is gone; and history is a dimension of the present. Lastly, she stresses the necessity to keep on searching, to continue with the imaginative quest - this can show itself, for example, in broad-minded interdisciplinarity and in the many encounters that happen, more by accident than by design, when different semantic systems and different discursive codes acknowledge each other. ${ }^{31}$

Ermarth's quirky, complex, reiterative, layered anthematic narrative opens up into several directions, moves on several temporal levels and positions the past and the present in overlapping folds. As a theoretical design, it represents a new way of describing and visualizing what historiography does and how it works. But we have already seen it put to practice in different ways by several historians who have refused a traditionalist agenda and experimented with their ways of telling. It is not a final solution, but it is a novel formulation that can set us thinking. In all its abstract visuality, it is among the most concrete of suggestions of a way forward.

\section{Works Cited}

BREWER, JOHN, Sentimental Murder. Love and Madness in the Eighteenth Century, London 2005.

Certeau, Michel De, The Possession at Loudun, trans. by Michael B. SMITH, Chicago/London 2000.

COHEN, ThOMAS V., Love and Death in Renaissance Italy, Chicago/London 2004.

Cressy, DAVD, Travesties and Transgressions in Tudor and Stuart England. Discord and Dissension, Oxford 2000.

31 ERMARTH, 2004, p. 81f.; ID., 2011, p. 111-113. 
DARNTON, ROBERT, The Great Cat Massacre and Other Episodes in French Cultural History, London 1984.

Davis, NATALIE ZEMON, The Return of Martin Guerre, Cambridge, Mass./ London 1983.

ID., Women on the Margins. Three Seventeenth-Century Lives, Cambridge, Mass. 1997.

DENING, GREG, Mr Bligh's Bad Language. Passion, Power and Theatre on the Bounty, Cambridge 1992.

ID., Performances, Chicago 1996.

ID., Beach Crossings. Voyaging across Times, Cultures, and Self, Philadelphia 2004.

ELEY, GEOFF, Is All the World a Text? From Social History to the History of Society Two Decades Later, in: The Historic Turn in the Human Sciences, ed. by TERRENCE J. MCDONALD, Ann Arbor 1999, p. 193-243.

ERMARTH, ElizaBETH, Ethics and Method, in: History and Theory 43, 4 (2004), p. 61-83.

ID., History in the Discursive Condition. Reconsidering the Tools of Thought, London 2011.

FULBROOK, MARY, Historical Theory, London/New York 2002.

GEERTZ, CLIFFORD, The Interpretation of Cultures. Selected Essays, New York 1973.

Grossberg, Lawrence, Cultural Studies in the Future Tense, Durham/ London 2010.

GUNN, SIMON, History and Cultural Theory, Harlow 2006.

HALTTUNEN, KAREN, Cultural History and the Challenge of Narrativity, in: Beyond the Cultural Turn. New Directions in the Study of Society and Culture, ed. by VicTORIA E. BONNELL/LYNN HuNT, Berkeley 1999, p. 165181.

HYVÄRINEN, MATTI, Towards a Conceptual History of Narrative, in: The Travelling Concept of Narrative, ed. by ID. et al., Helsinki 2006, p. 20-41.

ID., Prototypes, Genres, and Concepts: Travelling with Narratives, in: Narrative Works: Issues, Investigations, \& Interventions 2, 1 (2012), p. 10-32.

JENKINS, KEITH, Refiguring History. New Thoughts on an Old Discipline, London/New York 2003.

KANE, ANNE, Reconstructing Culture in Historical Explanation: Narratives as Cultural Structure and Practice, in: History and Theory 39, 3 (2000), p. $311-330$.
Munslow, Alun, The New History, Harlow 2003.

ID., Narrative and History (Theory and History), Houndmills 2007.

PARTNER, NANCY F., Making Up Lost Time: Writing on the Writing of History, in: Speculum 61, 1 (1986), p. 90-117.

Pinlainen, Kalle, The Moral of the Historical Story: Textual Differences in Fact and Fiction, in: New Literary History 33, 1 (2002), p. 39-60.

RADDEKER, HÉlÈne Bowen, Sceptical History. Feminist and Postmodern Approaches in Practice, London 2007.

SCHAMA, SIMON, Dead Certainties (Unwarranted Speculations), London 1991.

SCOTT, JOAN, Gender: A Useful Category of Historical Analysis, in: American Historical Review 91, 5 (1986), p. 1053-1075.

SEwell, William H., Logics of History. Social Theory and Social Transformation (Chicago Studies in Practices of Meaning), Chicago u. a. 2005.

SLACK, JENNIFER DARYL, The Theory and Method of Articulation in Cultural Studies, in: Stuart Hall. Critical Dialogues in Cultural Studies, ed. by DAVID MORLEY/KUAN-HSING CHEN, London 1996, p. 113-129.

WhITE, HAYDEN, The Content of the Form. Narrative Discourse and Historical Representation, Baltimore/London 1987.

ID., Figural Realism. Studies in the Mimesis Effect, Baltimore/London 1999. 


\section{Editorial}

In der Reihe Mainzer Historische Kulturwissenschaften werden Forschungserträge veröffentlicht, welche Methoden und Theorien der Kulturwissenschaften in Verbindung mit empirischer Forschung entwickeln. Zentraler Ansatz ist eine historische Perspektive der Kulturwissenschaften, wobei sowohl Epochen als auch Regionen weit differieren und mitunter übergreifend behandelt werden können. Die Reihe führt unter anderem altertumskundliche, kunst- und bildwissenschaftliche, philosophische, literaturwissenschaftliche und historische Forschungsansätze zusammen und ist für Beiträge zur Geschichte des Wissens, der politischen Kultur, der Geschichte von Wahrnehmungen, Erfahrungen und Lebenswelten sowie anderen historisch-kulturwissenschaftlich orientierten Forschungsfeldern offen.

Ziel der Reihe Mainzer Historische Kulturwissenschaften ist es, sich zu einer Plattform für wegweisende Arbeiten und aktuelle Diskussionen auf dem Gebiet der Historischen Kulturwissenschaften zu entwickeln.

Die Reihe wird herausgegeben vom Koordinationsausschuss des Forschungsschwerpunktes Historische Kulturwissenschaften (HKW) an der Johannes Gutenberg-Universität Mainz.

The Mainzer Historische Kulturwissenschaften [Mainz Historical Cultural Sciences] series publishes the results of research that develops methods and theories of cultural sciences in connection with empirical research. The central approach is a historical perspective on cultural sciences, whereby both epochs and regions can differ widely and be treated in an all-embracing manner from time to time. Amongst other, the series brings together research approaches in archaeology, art history, visual studies, literary studies, philosophy, and history, and is open for contributions on the history of knowledge, political culture, the history of perceptions, experiences and life-worlds, as well as other fields of research with a historical cultural scientific orientation.

The objective of the Mainzer Historische Kulturwissenschaften series is to become a platform for pioneering works and current discussions in the field of historical cultural sciences.

The series is edited by the Co-ordinating Committee of the Research Unit Historical Cultural Sciences ( $\mathrm{HKW}$ ) at the Johannes Gutenberg University Mainz.
Sonja Georgi, Julia Ilgner, Isabell Lammel, Cathlem Sarti, Christine Waldschmidt (Hg.)

\section{Geschichtstransformationen}

Medlen, Verfahren und Funktlonallslerungen

hlstorlscher Rezeptlon 


\section{INHALT}

Danksagung

Vorwort

\section{MORITZ BASSLER}

Geschichtstransformationen.

Medien - Verfahren - Funktionalisierungen

\section{Bedingungen, Modi und Funktionalisierungen von Geschichtstransformationen}

B|bllograflsche Informatlon der Deutschen Natlonalblbllothek

Die Deutsche Nationalbibliothek verzeichnet diese Publikation in der Deutschen Nationalbibliografie; detaillierte bibliografische Daten sind im Internet über http://dnb.d-nb.de abrufbar.

\section{(c) 2015 transcrlpt Verlag, Blelefeld}

Die Verwertung der Texte und Bilder ist ohne Zustimmung des Verlages urheberrechtswidrig und strafbar. Das gilt auch für Vervielfältigungen, UUbersetzungen, Mikroverfilmungen und für die Verarbeitung mit elektronischen Systemen.

Umschlagkonzept: Kordula Röckenhaus, Bielefeld

Korrektorat \& Satz: Cathleen Sarti

Printed in Germany

Print-ISBN 978-3-8376-2815-9

PDF-ISBN 978-3-8394-2815-3

Gedruckt auf alterungsbeständigem Papier mit chlorfrei gebleichtem Zellstoff. Besuchen Sie uns im Internet: $h$ ttp://www.transcript-verlag.de

Bitte fordern Sie unser Gesamtverzeichnis und andere Broschüren an unter: info@transcript-verlag.de

Narrative Transformations in Cultural History

ANU KORHONEN

Nach dem Schreiben. Abschreiben und

Umschreiben von Geschichte in der Frühen Neuzeit.....

SUSANNE RAU

Autopsie und Convivium. Wissenskulturen des

16. Jahrhunderts als Beispiel für

kulturelle Transformationen

ALBERT SCHIRRMEISTER 
Historismus in der Literatur des 19. und des

21. Jahrhunderts. Verwandlungsformen abstrakter

Teleologie in konkreten Sinn im historischen Erzählen .107

ANDREA JÄGER

Strategien der Geschichtstransformationen

in Themenparks

FIIIPPO CARLÀ \& FLORIAN FREITAG

\section{Narrative und Narrativisierungen von Geschichtstransformationen zwischen Fakt und Fiktion}

Approaching History and Fiction.

Daniel Defoe's Fiction and Writings on the Great Storm....

AINO MÄKIKALLI

Von der Paralogie zum Widerstreit.

Jean-François Lyotard und die Geschichtswissenschaft im Spiegel der (Post)-Moderne.

CHRISTIAN STERNAD

María Teresa Andruettos La mujer en cuestión (2003)

als Erzählung verwobener Geschichtsstränge.

VERÓNICA ABREGO

„Es war einmal..." historische Authentizität - Tarantinos Inglourious Basterds (2009): eine filmische Absage an die Dominanz des Faktischen? Narrative

Geschichtstransformationen durch

Märchen und Märchenmotivik .213

SABRINA GEILERT \& JULIANE VOORGANG
„Was anfangen mit der verlorenen Zeit?“ Eugen Ruges In Zeiten des abnehmenden Lichts (2011) als Beispiel einer Geschichtstransformation in der deutschen

Gegenwartsliteratur

ISABELLA FERRON

\section{Geschichtstransformationen im Kontext von Gesellschaftskritik und Erinnerungskultur}

Between Fact and Fiction: Transforming the Past in George Psalmanazar's Forged Histories of the Orient .259

JACQUELINE HYLKEMA

Verlebendigung der Antike. Zur Funktionalisierung von Geschichte in der Kulturkritik um 1900 am Beispiel von Stefan George und Alfred Schuler

EVA. WIEGMANN-SCHUBERT

".... in all dem zusammen noch ein bißchen Mensch".

H. G. Adlers poetische Transformationen erlebter

Geschichte

MARTIN MODLINGER

The Relationship between History and Fiction in the Folie Tristan de Berne and the Folie Tristan d'Oxford. .325 FIONA SUSLAK

Milton als Modell und Medium. Schlaglichter eines

Diskurses des englischen 18. Jahrhunderts .... .343 
Politisch konstruiert, filmisch demontiert. Der Diskurs des Glücks in der spanischen Konsumgesellschaft der 50er Jahre: Esa pareja feliz (1951) und

La vida por delante (1958).....

JULIA BRÜHNE

"Und herrlich tagt der Kosmos der Geschichte".

Geschichtstransformationen in Adolf Schottmüllers

Lyrikanthologie Klio (1840)

NIKOLAS IMMER

Geschichtstransformationen im Drama der Weimarer

Republik: Ernst Toller - Emil Ludwig - Alfons Paquet

CHRISTOPHER MEID

\section{Interkulturelle und postkoloniale} Geschichtstransformationen

Verräter und Verbrecher? Kulturelle Mittler in der kolonialen Historiografie und in postkolonialen Relektüren:

Geschichtstransformation am Beispiel der

iberischen Expansion

CORNELIA SIEBER

Prophesying the Future, Replotting the Past: The 'Blonds', the Last Constantine, and the Revision of the Fall

of Constantinople in Russia and Greece

MICHEL DE DOBBELEER \& EUGENIA RUSSELL

Toussaint Louverture in der französischen Romantik.

Die Transformation des haitianischen Revolutionsführers zum Widerpart Napoleon Bonapartes...
Lumina Sophie dite Surprise - die Konstruktion einer karibischen Jeanne d'Arc in der Literatur und

Historiografie des 21. Jahrhunderts

SARAH GRÖNING

Autorinnen und Autoren

Auswahlbibliografie

ISABELL LAMMEL 